Deiksis: Jurnal Pendidikan Bahasa dan Sastra Indonesia, 7 (1) Januari 2020

DOI: $10.33603 /$ deiksis.v7i1.3203

(p-ISSN 2355-6633, e-ISSN 2548-5490)

\title{
Kesetaraan Perempuan dan Polemik Budaya Patriarkal Dalam Novel Cinta Suci Zahrana
}

\author{
Ridzky Firmansyah Fahmi $^{1)}$, Riskha Arfiyanti' ${ }^{2)}$ \\ zhukhie@gmail.com ${ }^{1)}$, arfiyanti.riskha@gmail.com ${ }^{2)}$ \\ Universitas Siliwangi ${ }^{1)}$, Universitas Swadaya Gunung Jati ${ }^{2)}$
}

\begin{abstract}
Abstrak. Penelitian ini didasarkan atas temuan dalam novel Cinta Suci Zahrana karya Habiburrahman El-Shirazy yang mengangkat persoalan perempuan. Novel Cinta Suci Zahrana menarik untuk dikaji dari sudut pandang gender karena bernuansa feminisme. Namun, novel ini ditulis oleh pengarang laki-laki. Teori yang digunakan dalam penelitian ini ialah teori feminisme dan gender. Metode penelitian menggunakan deskriptif analisis dengan studi dokumentasi. Dari hasil penelitian ditemukan kecenderungan perempuan lajang yang berpendidikan dan berkarier tinggi acapkali mendapatkan desakan untuk segera menikah. Hal itu didasarkan masih kuatnya budaya patriarkal yang membentuk konstruksi sosial sehingga muncul anggapan bahwa setinggi-tingginya perempuan berpendidikan dan berkarier pada akhirnya akan mengurus hal-hal yang bersifat domestik. Novel Cinta Suci Zahrana mencerminkan realitas kehidupan masa kini, terutama bagi perempuan yang berkarier dan berpendidikan tinggi, tetapi belum menikah, seperti yang direpresentasikan tokoh Zahrana. Konflik yang dialami tokoh Zahrana merupakan representasi dari ketidaksetaraan gender pada masyarakat patriarkal bahwa pria cenderung bebas melakukan pilihan yang didukung oleh anggapan mayoritas sebagai sebuah kewajaran bahkan kebenaran.
\end{abstract}

Kata Kunci : Cinta Suci Zahrana, gender, patriarkal

\section{Pendahuluan}

Perempuan selalu menarik untuk dikaji-diperbincangkan. Ia selalu hadir dalam berbagai suara, warna, dan perspektif. Perempuan selalu mempunyai celah untuk menyelusup ke dalam ruang-ruang tanpa batas yang mampu ia tembusi. Selain memiliki daya pikat (tersendiri), ia pun memiliki kekuatan yang sangat khas, entah dari cara bertutur, bersikap, bahkan pemikiran, dan karya yang bisa menandingi kaum laki-laki. Sebagai seorang makhluk yang unik, ia memiliki intelegensi untuk merasa, meraba, dan menerjemahkan apa yang 'disentuhnya'. Namun persoalan perempuan tidak hanya pada daya tariknya, tidak hanya pada bentuk fisiknya, dan tidak hanya eksistensinya yang saat ini telah banyak mengungguli para laki-laki. Persoalan perempuan secara nyatanya memang lebih dekat dengan berbagai bentuk ketidakadilan. Entah apa yang menyebabkan perempuan identik berada dalam situasi rawan mendapatkan ketidakadilan dan mesti memperjuangkan haknya secara terbuka, baik dalam lingkup kehidupan rumah tangga maupun dalam lingkup sosial yang lebih luas.

Ketidakadilan perempuan banyak dijadikan riset. Susanti (2010) melakukan penelitian pada novel Кири-kири Malam karya Achmad Munif. Susanti melakukan penelitian dengan menggunakan analisis ketidakdilan gender yang didasarkan atas lima cakupan yaitu marginalisasi, subordinasi, stereotip, kekerasan, dan beban kerja. Hasil penelitian Susanti menyebutkan ketidakdilan gender yang dialami tokoh Sriyati dan Rum berupa kekerasan. Kekerasan yang dialami tokoh tersebut berupa kekerasan fisik dan seksual. Susanti 
Deiksis: Jurnal Pendidikan Bahasa dan Sastra Indonesia, 7 (1) Januari 2020

DOI: $10.33603 /$ deiksis.v7i1.3203

(p-ISSN 2355-6633, e-ISSN 2548-5490) menyimpulkan bahwa kekerasan yang dialami tokoh perempuan dalam novel Кири-kири Malam merupakan bentuk marginalisasi atas tuntutan perempuan terhadap haknya sebagai pribadi yang bebas dan berhak menentukan pilihan. Perempuan dianggap pribadi/kaum yang lemah yang tidak dapat diandalkan terlebih menjadi pemimpin. Bahkan tubuh perempuan pun dan kecantikan perempuan merupakan peluang bagi laki-laki untuk melakukan ketidakdilan gender dan dianggap sebagai sebuah kewajaran dalam budaya patriarkal.

Novel Cinta Suci Zahrana merupakan novel yang merefleksikan budaya masyarakat pada komunal tertentu yang berdecak kagum kepada perempuan yang berhasil meraih dan menyelesaikan pendidikan tinggi. Namun dalam novel ini pun direpresentasikan pandangan masyarakat yang masih memandang perempuan sebagai makhluk yang mesti tunduk pada aturan budaya yang mengikatnya. Peneliti tertarik meneliti novel ini sebab novel bernapaskan feminis ini ditulis pengarang laki-laki yang sebelumnya menulis novel bertema feminis juga. Dalam tiap karyanya, Habiburrahman El-Shirazy berupaya membangun konstruksi sosial yang didasarkan atas kesetaraan gender antara laki-laki dan perempuan dengan tidak menyalahi syariat agama. Novel-novelnya bertemakan religius, tetapi selalu ada tokoh perempuan yang memperjuangkan haknya dan harus bergelut dengan persoalan tafsir agama dan budaya masyarakatnya yang tinggal di sekitarnya.

\section{Metode}

Penelitian ini menggunakan metode deskriptif. Metode ini digunakan untuk menjelaskan relasi makna antara novel Cinta Suci Zahrana dan konstruksi gender. Pertamatama dilakukan pembacaan novel. Setelah itu dilakukan analisis identitas tokoh nutama dengan wacana gender yang dominan dalam pengaluran. Selanjutnya dilakukan interpretasi konstruksi gender yang didasarkan atas bukti teks. Kemudian dilakukan pembahasan dan terakhir dilakukan simpulan atas pembahasan.

\section{Hasil dan Pembahasan}

Karya sastra dapat menjadi representasi budaya masyarakat. Karya sastra merefleksikan gagasan, sikap, dan bentuk-bentuk berwujud yang merupakan hasil pemikiran masyarakat. Karya sastra juga dapat menjadi media kritik dan pembangunan wacana yang efektif sebab pembaca karya sastra akan memiliki pengalaman empiris tanpa merasa diajari. Pembaca karya sastra akan belajar pada apa yang diapresiasinya. Begitupun dengan novel Cinta Suci Zahrana yang menyuguhkan konflik batin tokoh Zahrana, seorang perempuan berpendidikan yang dicecar dan berjuang demi segera mendapatkan status sosial pernikahan dalam kehidupannya di masyarakat.

\section{a. Feminisme dan Gender}

Feminisme lahir awal abad ke-20 dan dipelopori oleh Virginia Woolf dalam bukunya yang berjudul A Room of One's Own (1929). Merujuk asal katanya, feminis yang berasal dari kata femme (woman) berarti perempuan yang bertujuan untuk memperjuangkan hak-hak kaum perempuan (jamak), sebagai kelas sosial. Feminis bertujuan menciptakan keseimbangan, 
Deiksis: Jurnal Pendidikan Bahasa dan Sastra Indonesia, 7 (1) Januari 2020

DOI: $10.33603 /$ deiksis.v7i1.3203

(p-ISSN 2355-6633, e-ISSN 2548-5490)

interelasi gender antara laki-laki dan perempuan. Feminis dapat diartikan sebagai sebuah upaya kaum perempuan menolak segala sesuatu yang memarginalkan, menyubordinasikan, dan merendahkan mereka dalam kehidupan sosial. Feminisme memiliki perhatian yang tinggi atas pentingnya kesetaraan laki-laki dan perempuan dalam bidang sosial, politik, dan ekonomi. Identitas seks dan gender laki-laki dan perempuan dibentuk konstruksi sosial. Gender merupakan perbedaan fungsi dan peran antara laki-laki dan perempuan yang dipengaruhi konstruksi sosial, dan bukan didasarkan atas perbedaan jenis kelamin. Kesetaraan gender dapat menjamin partisipasi perempuan untuk lebih aktif dan produktif dalam mengembangkan pemahaman sekait dengan perbedaan peran gender dalam masyarakat.

Gender terbagi atas dua kategori yakni identitas gender inti dan identitas peran gender. Identitas gender inti mengacu pada perasaan menjadi laki-laki atau perempuan yang terbentuk pada usia dua tahun dan didasarkan atas aspek biologis yang membedakan dirinya sebagai lakilaki atau perempuan. Sementara identitas peran gender mengacu pada perasaan individu atas gendernya sebagai maskulin atau feminin dan dipengaruhi faktor biologis, sosiologis, dan psikologis. Dalam rumusan ilmu-ilmu sosial, relasi gender diartikan sebagai aturan-aturan, tradisi-tradisi, dan hubungan-hubungan sosial timbal balik dalam masyarakat dan kebudayaan yang menentukan batas-batas feminin (dianggap bersifat keperempuanan) dan maskulin (dianggap bersifat kelelakian). Butler menolak pandangan bahwa seks (laki-laki atau perempuan) sebagai penentu dari gender (maskulin atau feminin), dan gender sebagai penentu orientasi seksual. Itu sebabnya, menurut Butler, bila seseorang memiliki identitas maskulin pada suatu waktu dan memiliki identitas feminis pada waktu yang lain merupakan hal yang wajar sebab identitas diperoleh dari tindakan performative yang selalu berubah-ubah (Meissner dalam Parthami, 2009, hlm. 9; Macdonald dalam Rohmaniyah, 2013, hlm. 59).

Ketidakadilan gender meliputi marginalisasi, subordinasi, stereotip, kekerasan, dan beban kerja. Marginalisasi merupakan keyakinan masyarakat terhadap suatu anggapan bahwa perempuan kurang dapat memiliki keterampilan dalam bidang publik sehingga tidak diberi kepercayaan untuk berkarier di wilayah publik. Itu sebabnya perempuan menjadi terpinggirkan dan tidak mendapat akses di wilayah publik. Stereotip merupakan pemberian label atau citra terhadap suatu objek yang berdampak pada ketidakadilan. Subordinasi merupakan anggapan bahwa perempuan merupakan makhluk yang lebih mengutamakan perasaan daripada logika. Kekerasan merupakan bentuk serangan baik berupa fisik maupun mental yang dilakukan salah satu jenis kelamin atau kelompok terhadap fisik atau mental seseorang lainnya. Beban kerja merupakan tanggung jawab yang diberikan secara penuh atau dibebankan kepada seseorang dan dianggap sebagai suatu kewajaran dan sudah menjadi tugasnya (Fakih, 2013, hlm. 12).

Tiga proporsi teori feminisme berbicara mengenai hubungan: a) karya sastra dan dunia nyata; b) karya sastra dan realitas yang bersifat politis; dan c) politik karya sastra yang berfokus pada perempuan. Pada proporsi pertama, sebuah teks merupakan bagian dari realitas. Teks dapat mewakili dan mendeskripsikan realitas, menciptakan realitas, dan menawarkan realitas lainnya sebagai alternatif. Pada proporsi kedua, hubungan antara kata dan realitas bersifat politis. Teks dan proses pembacaan yang dilakukan bersifat memaksa sehingga memunculkan keinginan berpolitik, yakni membaca karya sastra dengan cara tertentu dan menulis tentang apa 
Deiksis: Jurnal Pendidikan Bahasa dan Sastra Indonesia, 7 (1) Januari 2020

DOI: $10.33603 /$ deiksis.v7i1.3203

(p-ISSN 2355-6633, e-ISSN 2548-5490)

yang telah dibaca dengan motivasi mendapatkan kuasa untuk membuktikan perbedaan. Pada proporsi ketiga, perempuan kurang menunjukkan representasi riil mereka dan hanya berkutat dalam hal-hal yang berkaitan dengan kehidupan umum seperti pemaksaan atau eksploitasi fisiologi terhadap tubuh perempuan atau eksploitasi psikologis dan kultural. Dasar pemikiran dalam penelitian sastra berperspektif gender merupakan upaya pemahaman kedudukan dan peran perempuan seperti yang direpresentasikan dalam karya sastra (Robbins dalam Musthafa, 2008, hlm. 85; Sugihastuti, 2005, hlm. 15).

\section{b. Takbir Cinta Zahrana}

Novel Cinta Suci Zahrana merupakan novel yang ditulis oleh Habiburrahman El Shirazy. Novel ini berkisah mengenai seorang perempuan muda yang memiliki pendidikan tinggi berjenjang S-2, berkarier baik, tetapi belum juga mendapatkan jodoh. Tiap adegan dalam novel menampilkan sosok Zahrana sebagai perempuan yang aktif, cerdas, dan religius. Zahrana dihadirkan sebagai sosok perempuan yang idealis dan memegang teguh ajaran agama. Akhir cerita novel ini bernasib bahagia (happy ending). Cerita diakhiri dengan pernikahan Zahrana dengan seorang pemuda yang sempat menjadi mahasiswa bimbingannya untuk tugas akhir (skripsi). Adegan novel dimulai dengan menampilkan sosok Zahrana sebagai perempuan cerdas dan tangguh. Hal tersebut tampak pada adegan ketika Zahrana dihadirkan di hadapan mahasiswa jurusan. Ketika itu, Zahrana dikisahkan baru saja menyelesaikan studi magisternya. Zahrana dihadirkan sebagai tokoh inspiratif bagi mahasiswa: meski perempuan dan berhijab, tetapi tidak menghalangi kemauan untuk mendapatkan pendidikan tinggi.

Teknik pengungkapan novel ini dimulai dengan kehadiran Zahrana sebagai dosen muda teladan dan penuh dengan kreativitas serta dedikasi yang tinggi. Hal tersebut terlihat ketika Zahrana membantu membimbing skripsi mahasiswa tingkat akhir bernama Hasan, meskipun ketika itu Zahrana termasuk dosen yang baru bekerja di kampus tersebut. Zahrana dihadirkan sebagai sosok yang baik, idealis, tegas, mau membantu, berani mengambil keputusan, tetapi bersikap pasrah. Dialog antara Nina dan Hasan yang merupakan mahasiswa Zahrana menunjukkan bahwa Zahrana termasuk orang yang baik dan mau membantu. Hal tersebut tampak pada dialog Zahrana dan Hasan, mahasiswa yang dibimbingnya untuk penulisan skripsi. Hal itu terlihat pada kutipan berikut.

"Saya masih boleh konsultasi pada ibu tho. Meskipun ibu tidak di kampus ini lagi?"

"Boleh San. Kalian semua ibu persilakan dolan ke rumah ibu kapan saja." Kata Zahrana sambil memandang wajah mahasiswanya satu per satu (El-Shirazy, 2011, hlm. 20).

Sikap idealis Zahrana terlihat pada keputusannya untuk berkarier dan berpendidikan tinggi. Terbukti dengan banyaknya prestasi dan pujian yang ia peroleh berkat kegigihannya memperjuangkan pendidikan dan karier, seperti terlihat dalam kutipan berikut.

Tidak hanya itu, ia juga pernah mendapatkan penghargaan sebagai dosen paling

berdedikasi di kampusnya. Ia sangat disegani oleh sesama dosen dan dicintai oleh mahasiswanya. Ia juga disayang oleh keluarga dan para tetangganya. Bagi 
Deiksis: Jurnal Pendidikan Bahasa dan Sastra Indonesia, 7 (1) Januari 2020

DOI: $10.33603 /$ deiksis.v7i1.3203

(p-ISSN 2355-6633, e-ISSN 2548-5490)

perempuan seusianya, nyaris tidak ada yang kurang pada dirinya. Sudah berapa

kali ia mendengar pujian tentang kesuksesannya (El-Shirazy, 2011, hlm. 2).

Sikap idealis Zahrana terlihat dalam keteguhan hati ketika dihadapkan pada lamaran yang dilakukan oleh atasannya. Zahrana bersikukuh menolak lamaran karena ia memiliki kriteria tersendiri bagi calon suaminya. Hal itu terlihat dalam kutipan berikut.

Hari ini ia kembali diuji. Seseorang akan datang. Datang kepada orangtuanya untuk meminangnya. Ia masih bimbang harus memutuskan apa nanti. Ia sudah sangat tahu siapa yang akan datang. Dan sebenarnya ia juga sudah tahu apa yang harus ia putuskan. Meskipun pahit ia merasa masih akan bersabar meniti jalan terjal dan panjang sampai ia menemukan mutiara yang ia harapkan (ElShirazy, 2011, hlm. 4).

Bagi banyak perempuan dan bagi orang tua Zahrana, Zahrana sudah waktunya untuk menikah. Namun, Zahrana belum memikirkan pernikahan. Zahrana lebih memilih mengembangkan diri di luar wilayah rumah tangga terlebih dahulu. Pilihannya ini membuat pada akhirnya ia memiliki konflik batin tersendiri. Bagaimanapun, ia ingin membahagiakan orang tuanya dengan sebuah pernikahan. Hal ini membuat ibu Zahrana jengkel terhadap sikap anaknya, seperti terlihat dalam kutipan berikut.

Ada satu hal yang ia tangisi setiap malam. Setiap kali bermunajat kepada Sang Pencipta siang dan malam. Ia menangisi takdirnya yang belum juga berubah. Takdir sebagai perawan tua yang belum juga menemukan jodohnya. Dalam keseharian ia tampak biasa dan ceria. Ia bisa menyembunyikan derita dan sedihnya dengan sikap tenangnya (El-Shirazy, 2011, hlm. 2).

"Kamu masih nunggu yang bagaimana lagi, Nduk? Pak Karman memang agak tua, tapi ia berpendidikan dan kaya. Dia juga bisa tampak muda." (El-Shirazy, 2011, hlm. 11).

Sikap pasrah Zahrana terlihat pada saat Zahrana berbincang-bincang dengan ayah ibunya soal pernikahan. Ayahnya menyarankan agar Zahrana meminta bantuan kepada pimpinan pondok pesantren untuk membantu mencarikan jodoh untuknya. Hal itu terlihat dalam kutipan berikut.

Sang ayah berkata sambil terisak, "Saat pindah ke STM Al Fatah kamu bilang siapa tahu jodohmu di pesantren. Coba datanglah ke Pak Kiai. Coba kamu minta pada Pak Kiai untuk membantu mencarikan. Mungkin kamu akan ditemukan dengan santrinya!"

"Baiklah ayah, tak kurang ikhtiar saya. Untuk menemukan yang saya idamkan baiklah saya akan sowan ke tempat Bu Nyai dan Pak Kiai secepatnya." Jawab Zahrana sambil mengusap air matanya (El-Shirazy, 2011, hlm. 28).

Teknik pengungkapan peristiwa dalam novel cenderung linear. Namun ada pula yang berupa ingatan peristiwa, hanya saja dihadirkan dalam bentuk dialog. Hal tersebut tampak ketika Zahrana mengingat peristiwa teror yang dialaminya. Ketika itu, Zahrana sedang dirawat di rumah sakit karena mengalami guncangan kejiwaan yang dahsyat setelah gagal menikah karena calon suaminya meninggal dunia disebabkan kecelakaan (yang sesungguhnya direkayasa). Zahrana berdialog dengan temannya yang menyatakan sepertinya apa yang menimpa calon suaminya (Rahmad) ialah ulah dekan tempat Zahrana sempat mengajar di universitas tersebut yang menyimpan dendam karena lamarannya ditolak oleh Zahrana. 
Deiksis: Jurnal Pendidikan Bahasa dan Sastra Indonesia, 7 (1) Januari 2020

DOI: $10.33603 /$ deiksis.v7i1.3203

(p-ISSN 2355-6633, e-ISSN 2548-5490)

Zahrana beranggapan kejadian yang menimpa Rahmad bukan kecelakaan biasa, tetapi pembunuhan sebab Zahrana ingat ketika dekan tersebut mengirimi pesan via telepon genggam dan pos-el yang mengatakan tidak akan berhenti mengganggu hidup Zahrana. Hal itu terlihat dalam kutipan berikut.

Zahrana tersentak. Kata-kata Pak Karman bagai aliran listrik yang menyengatnya. Kata-kata itu menguatkan keyakinannya bahwa yang menterornya selama ini adalah Pak Karman. Dan bagaimana bisa Pak Karman tahu ia membeli gaun pengantin itu dari Solo (El-Shirazy, 2011, hlm. 54).

Selain tokoh Zahrana, terdapat tokoh Hasan, mahasiswa Zahrana yang sesungguhnya menyukai Zahrana. Hasan sempat kecewa karena mengetahui Zahrana akan menikah. Hasan dihadirkan sebagai tokoh yang rajin dan berkarakter baik. Hal tersebut terlihat dalam dialog antara Hasan dan Zahrana ketika keduanya berbincang melalui telepon. Dalam percakapan tersebut, Zahrana memuji Hasan sebagai anak yang rajin dan Zahrana mengungkapkan kekagumannya karena Hasan sudah pandai berbisnis meskipun usianya masih muda.

Rahmad, laki-laki yang dijodohkan dengan Zahrana dan menjadi calon suami Zahrana, dihadirkan sebagai sosok yang baik, taat, dan beragama. Rahmad hadir sebagai seorang tukang kerupuk yang jujur dan religius. Selain itu, ada pula tokoh dekan fakultas tempat Zahrana bekerja yang memiliki tabiat buruk. Ia mendendam setelah lamarannya ditolak Zahrana. Bahkan, ia pula yang merancang kematian Rahmad dan mengunjungi Zahrana dengan wajah yang berbinar ketika Zahrana masih berduka dan dirawat di rumah sakit.

\section{c. Perempuan dan Budaya Patriarkal}

Patriarkal merupakan sistem yang mengelompokkan kehidupan sosial masyarakat berdasarkan garis keturunan laki-laki. Sistem ini secara otomatis menempatkan laki-laki memiliki posisi dan peran lebih tinggi daripada perempuan dalam bidang sosial, budaya, ekonomi, dan sebagainya. Hal itulah yang membuat perempuan kurang mendapat posisi dan peran di wilayah-wilayah tersebut secara otonom. Hal itu didasarkan pada seksualitas perempuan yang menempatkannya pada posisi yang tidak adil karena perannya dalam wilayah publik dikonstruksi oleh berbagai mitos, budaya, hukum, nilai sosial, dan agama (Sastriyani, 2007, hlm. 65; Pinem, 2009, hlm. 42; Widianti, 2005, hlm. 10).

Cinta Suci Zahrana berbicara perjuangan perempuan dalam sudut pandang budaya patriarkal sebab dalam novel dideskripsikan Zahrana sebagai perempuan yang dapat mengakses wilayah publik yang selama ini didominasi laki-laki, tetapi harus "terjebak" dalam stigma budaya patriarkal sekait dengan pernikahan. Novel ini lebih mengedepankan sisi religius atas percintaan yang dianut oleh Zahrana. Zahrana ialah sosok perempuan yang berpendidikan tinggi dan tidak mengenal istilah berpacaran. Itu sebabnya, selain fokus pada karier dan pendidikan, Zahrana pun memilih tidak berpacaran sebab Zahrana terkategori sebagai perempuan muslim yang memegang teguh syariat untuk tidak berpacaran.

Novel ini menunjukkan perspektif gender yang kuat ketika sosok Zahrana dihadirkan sebagai perempuan cerdas, berpendidikan tinggi, dan memiliki kemampuan berkarier yang baik. Meskipun dalam penceritaan selanjutnya, kesetaraan gender yang diperjuangkan Zahrana pada akhirnya harus dinegosiasikan dengan kultur perempuan dewasa dan cukup mapan untuk 
Deiksis: Jurnal Pendidikan Bahasa dan Sastra Indonesia, 7 (1) Januari 2020

DOI: $10.33603 /$ deiksis.v7i1.3203

(p-ISSN 2355-6633, e-ISSN 2548-5490)

segera berumah tangga. Pada persoalan ini, Zahrana tampak seakan "menyerah" dengan meminta bantuan untuk dijodohkan oleh orang tuanya bahkan Zahrana sendiri meminta bantuan untuk dicarikan pasangan melalui pimpinan pondok pesantren. Di luar kuatnya budaya patriarkal memengaruhi alur novel, terlihat jelas bahwa novel ini berupaya memberikan warna yang berbeda sekait perjuangan perempuan dalam menyetarakan dirinya agar juga dapat mengakses pendidikan tinggi, karier yang cemerlang, dan pekerjaan di wilayah publik bukan di ranah domestik. Hal ini sekait dengan yang dikemukakan Djajanegara (2000, hlm 4) bahwa inti tujuan feminisme adalah meningkatkan kedudukan dan derajat perempuan agar sama atau sejajar dengan kedudukan serta derajat laki-laki. Perjuangan serta usaha feminisme untuk mencapai tujuan ini salah satu caranya ialah dengan memperoleh hak dan peluang yang sama dengan yang dimiliki laki-laki dalam bidang yang berkaitan dengan sosial dan wilayah publik.

Selain ditulis menggunakan perspektif feminis, novel ini sangat kuat dengan nuansa agama. Selain dari prinsip Zahrana yang tidak mau berpacaran, nuansa religius tampak pada syarat yang diberikan Zahrana kepada calon suaminya yang dipilihkan oleh ayahnya. Zahrana meminta pelamar yang datang untuk mengaji. Jika pelamar yang datang bisa mengaji dengan baik, maka Zahrana akan menikah dengan pelamar tersebut. Namun, tidak ada satu pun pelamar yang mampu mengaji. Itu sebabnya Zahrana akhirnya meminta bantuan kepada pemimpin pondok pesantren. Kehadiran pondok pesantren pun menjadi isu kuat dalam novel ini yang sangat menonjolkan sisi religiusitas dalam tiap adegannya. Pun ketika Zahrana keluar dari kampus tempatnya bekerja, Zahrana mengajar di sekolah agama (MA) setingkat SMA. Hal tersebut menunjukkan bahwa novel ini syarat dengan unsur religius. Selain itu, ketika Zahrana mengemukakan syarat calon suami yang diinginkan, Zahrana mengemukakan bahwa ia tidak mencari calon suami dengan pendidikan dan ekonomi yang tinggi. Bagi Zahrana, memiliki calon suami yang paham ajaran agama sudah menjadi syarat utama. Ia tidak menginginkan calon suami yang berpendidikan tinggi atau memiliki penghasilan yang tinggi pula, cukup hanya dengan paham ajaran agama dan bisa membimbing Zahrana, itu sudah merupakan hal yang ideal bagi Zahrana. Prinsip Zahrana ini ditunjukkan melalui dialog Zahrana kepada ibunya, seperti terlihat dalam kutipan berikut.

"Saya tidak menunggu yang bagaimana-bagaimana Bu. Saya menunggu lelaki saleh yang pas di hati saya. Itu saja." Jawab Zahrana (El-Shirazy, 2011, hlm. 11).

Prinsip ini tampak juga pada dialog antara Zahrana dan Bu Nyai seperti dalam kutipan berikut.

"Saat ini status, strata, kedudukan sosial, pendidikan dan lain sebagainya tidak jadi pertimbangan saya Bu Nyai. Saya hanya ingin suami yang baik agamanya. Baik imannya dan bisa jadi teladan untuk anak-anak kelak. Itu saja. " (El-Shirazy, 2011, hlm. 29).

Novel Cinta Suci Zahrana memberikan pengetahuan secara utuh mengenai nilai-nilai agama yang menjadi dasar kehidupan keseharian. Mulai dari memegang prinsip tidak berpacaran, sampai syarat pasangan yang harus memahami agama dengan baik. Novel ini memberikan amanat bahwa agama tidak boleh dilupakan meski kita mengejar dunia. Agama menjadi pilar dalam berperilaku sehari-hari. 
Deiksis: Jurnal Pendidikan Bahasa dan Sastra Indonesia, 7 (1) Januari 2020

DOI: $10.33603 /$ deiksis.v7i1.3203

(p-ISSN 2355-6633, e-ISSN 2548-5490)

Budaya patriarkal tampak kuat dalam novel ini. Hal tersebut terlihat dalam beberapa adegan, terlebih ketika orang tua Zahrana menginginkan anaknya segera menikah dan mencarikan jodoh untuknya. Pada adegan tersebut tampak bahwa perempuan yang belum menikah akan menjadi bahan perbincangan di masyarakat. Banyak sebutan disematkan untuk perempuan dalam kondisi ini. Seolah-olah begitu sulit bagi perempuan ketika harus hidup di masyarakat. Hal ini pula yang membatasi gerak langkah perempuan dalam posisi seperti ini di tengah kehidupan masyarakat. Dalam pandangan budaya patriarkal, perempuan tidaklah pantas menikah di usia terlalu matang. Di samping itu, perempuan pun dianggap pantas jika menikah dengan laki-laki yang usianya lebih tua. Jika perempuan lebih tua daripada laki-laki, hal itu akan terlihat agak janggal karena perempuan lazimnya mengikuti laki-laki dan laki-laki memiliki kuasa atas rumah tangga sebagai pemimpin atau kepala keluarga. Peran sosial itulah yang membentuk konstruksi sosial jika perempuan harus 'dinikahi' bukan 'menikahi' sebab dalam sebuah pernikahan laki-laki yang memiliki peran besar untuk menentukan. Pun perempuan mesti memiliki pasangan yang lebih tua sebab dianggap akan dapat mengayominya.

Kuatnya representasi budaya patriarkal pun terlihat ketika Zahrana yang berpendidikan tinggi harus menurunkan syarat untuk calon suaminya yaitu yang tidak berpendidikan tinggi, cukup saja dengan pemahaman agama yang baik. Dalam hal ini terlihat bahwa perempuan yang memiliki karier yang bagus dan jenjang pendidikan tinggi, cenderung susah mendapat pasangan karena laki-laki akan merasa minder sebab perempuannya lebih tinggi daripada laki-laki (dari segi pendidikan, penghasilan, jabatan, dan pemikiran). Budaya patriarkal dalam novel ditunjukkan pada dialog Ibu Nyai dalam kutipan berikut.

"Saya yakin tidak mudah mencari yang selevel denganmu, anakku. Jujur saja

kalau misalnya ada yang selesai S.2 umurnya sama denganmu dia akan memilih yang lebih muda darimu. Lelaki itu umumnya punya ego, tidak mau isterinya lebih pinter dan lebih tua darinya. Tapi ya tidak semua lelaki lho. Sekali lagi tidak mudah mencarikan jodoh yang pendidikannya harus tinggi seperti kamu juga saleh. Kalau boleh tahu, kalau strata pendidikannya tidak setinggi kamu bagaimana?" (El-Shirazy, 2011, hlm. 30).

Laki-laki dianggap memiliki nilai kepantasan dalam memimpin dan mempunyai kuasa atas pengaturan kehidupan sosial (bermasyarakat) dan rumah tangga (berkeluarga). Berbagai persoalan ketidakadilan yang dialami perempuan muncul karena adanya anggapan dalam konstruksi sosial di masyarakat bahwa laki-laki memiliki kuasa lebih terhadap perempuan (Darwin, 2001, hlm. 3). Meski dalam hal pendidikan dan karier saat ini perempuan sudah mendapatkan porsi yang sangat terbuka, namun ketidakdilan dalam konteks budaya patriarkal masih mengakar kuat. Pandangan ini memicu anggapan bahwa setinggi-tingginya pendidikan dan karier perempuan, tugas utamanya adalah mengurus rumah tangga atau 'kembali ke dapur'. Dalam budaya patriarkal, perempuan mempunyai tugas melayani laki-laki dengan sepenuh hati. Tugas semacam itu tidak memerlukan pendidikan yang tinggi. Anggapan perempuan hanya berkutat pada wilayah domestik membuat perempuan tidak dapat memilih dan hanya harus menerima pada keputusan yang sudah menjadi kebiasaan.

Novel ini merepresentasikan realitas kehidupan masyarakat saat ini. Dalam budaya patriarkal perempuan yang berpendidikan tinggi, berkarier cemerlang, dan belum menikah di 
Deiksis: Jurnal Pendidikan Bahasa dan Sastra Indonesia, 7 (1) Januari 2020

DOI: $10.33603 /$ deiksis.v7i1.3203

(p-ISSN 2355-6633, e-ISSN 2548-5490)

usia yang matang dianggap sesuatu yang tidak lazim dalam pandangan masyarakat. Ketidakdilan gender dalam bentuk stereotip bahwa perempuan selayaknya segera menikah di usia yang tak terlalu matang atau tua masih cukup melekat di masyarakat dan dianggap sebagai suatu ketidakwajaran. Berbeda halnya dengan laki-laki yang berpendidikan tinggi, berkarier, dan berusia matang kemudian belum menikah menjadi sesuatu yang dianggap wajar, lazim. Budaya patriarkal yang membentuk konstruksi sosial mengharuskan perempuan untuk menikah dan mengurus keluarga dalam batas usia yang sudah sewajarnya.

\section{Simpulan}

Problematik gender tokoh perempuan dalam Cinta Suci Zahrana yakni dihadapkan pada situasi yang harus menerima kenyataan bahwa sepintar apa pun perempuan pada akhirnya harus mengalah pada budaya patriarkal yang menempatkan perempuan sebagai pihak yang "perlu" laki-laki dan status pernikahan. Bentuk ketidakadilan gender tokoh perempuan dalam Cinta Suci Zahrana yaitu status pernikahan menjadi indikator kesuksesan perempuan dalam konteks kehidupan bermasyarakat. Bentuk perjuangan gender tokoh perempuan dalam Cinta Suci Zahrana yaitu dengan menerima kondisi yang dialami sebagai bentuk pengorbanan untuk citacitanya dan kebahagiaan orang tuanya.

\section{Daftar Pustaka}

Darwin, M. (2001). Menggugat budaya patriarki. Yogyakarta: Ford Foundation \&

Pusat Penelitian Kependudukan.

Djajanegara, S. (2000). Kritik sastra feminis: sebuah pengantar. Jakarta: Gramedia Pustaka Utama.

El-Shirazy, H. (2011). Cinta suci Zahrana. Jakarta: Ihwan Publishing House.

Fakih, M. (2013). Analisis gender dan transformasi sosial. Yogyakarta: Pustaka Pelajar.

Musthafa, B. (2008). Teori dan praktik sastra dalam penelitian dan pengajaran. Bandung: Sekolah Pascasarjana Universitas Pendidikan Indonesia.

Parthami, P.W. (2009). Konstruksi identitas jender. Depok: FPsi UI.

Pinem, S. (2009). Kesehatan reproduksi \& kontrasepsi. Jakarta: Trans Media.

Rohmaniyah, I. (2013). "Gender, androsentrisme, dan sexisme dalam tafsir agama". Welfare, Vol.2 No.1, pp. Januari - Juni 2013.

Sastriyani, S.S.H. (2007). Glosarium, seks, dan gender. Yogyakarta: Carasuati Books.

Sugihastuti. (2002). Kritik sastra feminis. Yogyakarta: Pustaka Pelajar.

Susanti, E. (2010). "Analisis ketidakadilan gender pada tokoh perempuan dalam novel "kupukupu malam" karya Achmad Munif". Artikulasi, Vol.10 No.2 Agustus. Daring. Tersedia di:

https://www.google.co.id/url?sa=t\&rct=j\&q=\&esrc=s\&source=web\&cd=1\&cad=rja\& uact=8\&ved=0ahUKEwiUlp7E9PvUAhWBqo8KHXKJAeIQFggpMAA\&url=http\%3 A\%2F\%2Fejournal.umm.ac.id (Diakses pada 30 Juni 2017)

Teeuw, A. (1984). Sastra dan ilmu sastra pengantar teori sastra. Jakarta Pusat: PT Dunia Pustaka Jaya. 
Deiksis: Jurnal Pendidikan Bahasa dan Sastra Indonesia, 7 (1) Januari 2020

DOI: $10.33603 /$ deiksis.v7i1.3203

(p-ISSN 2355-6633, e-ISSN 2548-5490)

Widianti, A. (2005). Hukum berkeadilan gender. Jakarta: Kompas. 